\title{
INTERNATIONAL JOURNAL OF PRECLINICAL AND CLINICAL RESEARCH
}

\section{REVIEW ARTICLE}

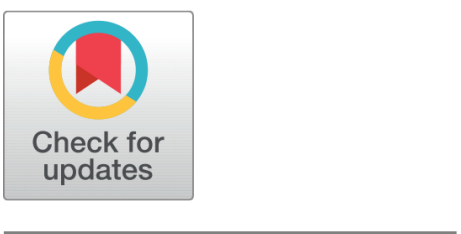

OPEN ACCESS

Received: 05-02-2021

Accepted: 29-03-2021

Published: 06-04-2021

Citation: Shreekrishna HK, Rao AB. (2021). Consent in medical practice. International Journal of Preclinical \& Clinical Research. 2(1): 13-17. https:/ /doi.org/10.51131/IJPCCR/v2i1.4

* Corresponding author.

krishnashree61@yahoo.com

Funding: None

Competing Interests: None

Copyright: ( 2021 Shreekrishna \& Rao. This is an open access article distributed under the terms of the Creative Commons Attribution License, which permits unrestricted use, distribution, and reproduction in any medium, provided the original author and source are credited.

Published By Basaveshwara Medical College \& Hospital, Chitradurga, Karnataka

\section{ISSN}

Print: $X X X X-X X X X$

Electronic: $X X X X-X X X X$

\section{Consent in medical practice}

\author{
H K Shreekrishna ${ }^{1 *}$, Aruna B Rao ${ }^{2}$ \\ 1 Professor, Department of Forensic medicine and toxicology, Basaveshwara Medical College \\ and Hospital, Chitradurga, 577502, Karnataka \\ 2 Senior Resident, Department of Psychiatry, Basaveshwara Medical College and Hospital, \\ Chitradurga, 577502, Karnataka
}

\section{Abstract}

Consent is an expression of autonomy and represents the right of a patient to make a decision in a medical matter concerning him. Consent is not just a procedural formality but also a legal requirement. The process of informed consent occurs when communication between a patient and physician results in the patient's authorization or agreement to undergo a specific medical intervention. In India, the number of suits against doctors is increasing because of failure to take informed consent or inadequate consent from patients for various procedures. Any examination of a patient by the doctor without his consent amounts to assault (351IPC). Ignorance of laws is not a defense in negligence cases, so every practicing doctor should be aware of their responsibilities about consent in medical practice. Consent is not an option but a necessity in medical practice.

Keywords: Consent; informed consent; autonomy

\section{Introduction}

The origin of the word consent is from the French word consente and Latin word consentire, which means cotogether+sentire feel. Consent implies agreement to accept the consequences of an action. Legally, two or more persons are said to consent when they agree upon the same thing in the same sense. ${ }^{(1)}$ Consent means an agreement, compliance or permission given voluntarily without any compulsion. ${ }^{(2)}$ Self-defense of the body (IPC sections 96 to102, 104, 106) provides the right to the protection of bodily integrity against invasion by others. The declaration of Helsinki (1964) adopted by the world medical association has emphasized the importance of obtaining informed consent for the subject of the aims, methods, anticipated benefits, potential hazard, and discomfort which the study may entail. ${ }^{(3)}$

\section{Kinds of consent}

\section{Implied consent}

The demeanor, behavior and actions of the patient indicate his consent. Trust and empathy from the basis of implied consent and are limited to inspection, palpation, percussion, auscultation except private parts in a standard professional 
manner. Beyond basic procedures implied consent is legally risky.

\section{Expressed consent}

In expressed consent, a patient specifically permits a physician to undertake diagnosis and treatment of a specific problem. An expressed consent can be written or verbal. Verbal consent is also legally valid but in a court of law, it may face a problem of credibility more so in cases where the patient has died. Expressed consent conforms to the doctrine of informed consent to be legally acceptable.

Informed Consent is a continuous process, which includes the exchange of information and the development of choices. If after due information the patient gives contradictory or doubtful signals in a particular procedure, then he also has the right to withhold consent at any point of time of the ongoing procedure. Informed Consent is now accepted as the cornerstone of medical practice. ${ }^{(4,5)}$ If after due information the patient gives contradictory or doubtful signals in a particular procedure, then he also has the right to withhold consent at any point of time of the ongoing procedure.

Tacit consent: is the failure of the patient to disagree or dissent. ${ }^{(6)}$ Here a patient not agreeing to a procedure has to take action to refuse if he does want not the procedure to be done on him.

Embodied:consent is an assessment of thepatient's body language for consent to treatment prior to and during treatment. ${ }^{(7)}$

Proxy consent: When a person is incapable of giving expressed consent a substituted consent can be taken from the next of kin. Generally accepted order is spouse, adult child, parents, siblings, lawful guardians.

Loco Parentis : In an emergency involving children, when their parents or guardians are not available, consent is taken from the person in charge of the child e.g. a school teacher can give consent for treating a child who becomes sick during a picnic away from home town, or the consent of the headmaster of a residential school.

\section{Necessity for obtaining Consent:}

1. Examining or treating a patient without his consent amounts to assault.

2. Consent respects the principle of biomedical ethics

3. Consent shows respect for the privacy and dignity of his patient

4. Consent protects legal action in case of medical negligence as this acts as proof of disclosure of material facts

5. Protection has been provided to doctors as per sec 88 IPC who have obtained informed consent which states act not intended to cause death, done by consent in good faith for person's benefit

\section{Procedure to take consent}

Consent must be obtained before treatment begins. It should be confirmed at the time of procedure. ${ }^{(8)}$ It should be taken in the patient's vernacular language. Asking the patient for consent while treatment is in progress may adversely influence the patient's decision-making and is not recommended. ${ }^{(9)}$ Consent must be taken from the patient himself. In Dr. Ramcharan Thiagarajan Facs versus Medical Council of India case, ${ }^{(10)}$ disciplinary action was awarded to the surgeon for not taking proper informed consent for the entire procedure of kidney and pancreas transplant surgery from the patient.

For changes in treatment (introducing a different type of technique), the full process of informed consent must be undertaken and consent explicitly obtained verbally or in writing. The patient should also be made aware that this ongoing consent (voluntarily) can be withheld at any point of time during treatment or procedure.

Legal validity of consent-Criteria for consent to be legally valid is

- A person of sound mind should give it.

- It should be based on correct and adequate information

- It should not have been obtained by fraudulent means

- In situations of a medical emergency, consent to lifesaving measures is implied.

- A person who is legally competent to give it.

\section{Components of informed consent}

\section{Disclosure of information}

Information to disclose to the patient include ${ }^{(11,12)}$

- The patient's diagnosis

- The nature and purpose of a proposed treatment or procedure

- The risks and benefits of a proposed treatment or procedure

- Alternatives and associated risks and benefits

- The risks and benefits of not receiving or undergoing a treatment or procedure

- The special precautions required postoperatively

- Questions asked by patient and explanation provided

\section{Free and voluntary decision-making}

A patient has to be given full opportunity to decide a medical matter concerning him. Consent that is given must be 
intelligent, informed and voluntary, the decision taken freely by the patient himself.

\section{Competence to decide}

Informed consent has to be given by a person who meets the following criteria

- He/She should be sound mind

- He/She should be able to comprehend the implications of his consent

- He/She should be at least twelve years old.

\section{Medical paternalism}

Doctor taking a decision on the type of treatment based on medical facts without the patient's input and participation which is against the principle of respect for the person and patient autonomy.

\section{Invalid informed consent}

As per Section 90 of IPC, if any consent given under the following circumstances will not be true consent.

1. By a person under fear of injury or,

2. By a person who is under the misconception of the facts and person who obtain consent knows or has reason to believe that or consent was given in consequence of such fear/misconception.

3. By intoxicated person or,

4. By a person who is of unsound mind or, unable to understand the nature and consequences of that to which he gives consent.

5. By a person who is below the age of $12 \mathrm{yrs}$.

\section{Informed refusal}

If after knowing about the procedure, its side effects, and other information related to the procedure patient declines or refuses to undergo the procedure, it must be taken in written. Treatment cannot be forced upon any individual who does not want to receive it, except in a very few circumstances like issues associated with public health, military personnel, or prisoners.

\section{Exceptions to obtaining consent}

1. Therapeutic privilege

2. Emergency life-threatening situation

\section{Therapeutic privilege}

It is an exception to the rule of full disclosure that a doctor can withhold information of remote or theoretical risks if he/she feels that it would be psychologically damaging or harm the patient if disclosed and who may refuse treatment when there are little risks. ${ }^{(13)}$ The doctor should record his decision in the case sheets mentioning his intentions and reasons. Doctors have an ethical duty to share information with their patients for their interest.

\section{Emergency life-threatening situation}

As per sec.92 IPC any harm caused to a person in good faith even without that person's consent is no offense if the circumstances are such that it is impossible for that person to signify consent and has no guardian or other person in lawful charge of him from whom it is possible to obtain consent in time for the thing to be in benefit.

In an emergency, a comatose patient requiring immediate treatment, the mentally ill person requiring treatment when a legal guardian is not available, an intoxicated patient who temporarily lacks the capacity to consent but requires treatment consent is implied.

\section{Consent in relation to $53 \mathrm{Crpc}$}

Under Sec $53^{(1)}$ Cr .P.C. ${ }^{(14)}$ when a person is arrested on a charge of committing an offense of such a nature and alleged to have been committed under such circumstances that there are reasonable grounds for believing that an examination of his person will afford to evidence as to the commission of an offense, it shall be lawful for a registered medical practitioner, acting at the request of a police officer, not below the rank of sub-inspector, and for any person acting in good faith in his aid and under his direction, to make such an examination of the person arrested as is reasonably necessary in order to ascertain the facts which may afford such evidence, and to use such force as is reasonably necessary for that purpose. Reasonable ground for believing that an examination of the accused will afford to evidence to the commission of an offense is the bonafide belief of the police officer. The registered medical practitioner is not concerned with it.

Under section $53^{(2)}$ Cr .P.C. ${ }^{(14)}$ whenever the person of a female is to be examined under this section, the examination shall be made only by, or under the supervision of, a female registered practitioner. An accused released on bail is also a person arrested for the purpose of section 53 Cr.P.C.

Consent in relation to $\mathbf{5 4 C r P C}$-When a person who is arrested may request the magistrate that examination of his body will afford evidence which will disprove the commission by him of any offense or which will establish the commission by any other person of an offense against his body, the magistrate may direct the examination of such person by a registered medical practitioner, unless the magistrate considers that the request is made for the purpose of vexation or delay the justice. 


\section{Consent and age}

Sec 87 I.P.C. - A person under the age of 18 years cannot give valid consent, whether expressed or implied, to suffer any harm which may result from an act not intended or not known to cause death or grievous hurt.

Sec 89 I.P.C. - a child under 12 years of age cannot give valid consent to suffer any harm which can occur from an act done in good faith and for its benefit, e.g. consent for an operation. Only a guardian can give such a consent

Under section 375 I.P.C. -Sexual intercourse with or without the complainant's consent when such complainant is under eighteen years of age amounts to sexual assault.

As per The Transplantation of Human Organs Act1994 and transplantation of human organ act(amendment ) act 2011, Donor means any person not less than eighteen years of age, who voluntarily authorizes the removal of any of his human organs for therapeutic purposes. For cadaver donor transplants, informed consent from the next of kin should be taken. If prior consent for organ donation before death is given in the presence of two or more witnesses, then transplantation of the organ should be presumed and is permissible without seeking further consent. ${ }^{(15)}$ The minimum age for donating blood as mentioned is eighteen years for a blood donor. ${ }^{(16)}$

\section{Consent by spouse}

Consent of one spouse is not necessary for the treatment of another. The spouse has no right whatsoever to withhold consent to any operation including gynaecological operations which is essential to safeguard the health of the other spouse. However, it is essential that spousal consent should be taken where there is a possibility of treatment-induced complication of sterility or impotence which affect the marital rights of either spouse are involved.

As per the MTP ACT 1971, does not require spousal consent for MTP, presuming that the husband has no legal right to participate in question concerning the pregnancy of his wife. In Assisted Reproductive Technologies informed consent should be taken from the spouses as well as the donor, as the case may be, for possible side effects, and the risk of treatment.

As per the Delhi Artificial Insemination Act 1995, written consent of both husband and wife seeking artificial insemination and also consent for single screen semen for HIV through enzyme-linked immunosorbent assay (ELISA) should be taken. ${ }^{(17)}$ Consent given for an illegal act is not valid e.g. Criminal abortion. The doctor is punishable if he performs such an act even with consent from the patient.

\section{Consent in Psychiatry}

They can be admitted or treated or discharged from a psychiatric hospital as per the guidelines laid in Indian Mental Health Act $1987^{(18)}$. As far as the emergency is concerned they can be treated as per IPC 92 and Article 21 of the Indian Constitution. None of such insane persons should be operated on as far as he/she is alive for organ or tissue donation ${ }^{(19)}$.

When an unconscious / unknown patient is admitted to the hospital, the medical superintendant/incharge of hospital can give consent for treatment. Consent of deceased relatives is required for conducting the pathological autopsy. In medico legal autopsy, consent is not required by guardians or legal heirs.

All the radiological investigations which involve isotopes, dyes, or other image enhancers and treatment by chemotherapy and radiotherapy should involve consent for treatment after proper disclosure of side effects and further disabilities.

Research studies or clinical trials should be conducted and have informed consent as per the guidelines laid by the Indian Council of Medical Research. ${ }^{(20)}$ Video recording of the informed consent process can be done with prior consent for the same and this should be documented. This is commonly done in organ transplantation procedures.

\section{Summary and conclusion}

Informed consent was practically non-existent the time COPRA (Consumer Protection Act) came into existence. This is seen as more of a legal requirement than the moral obligation on the part of the doctor towards his patient. Consent should be taken before the commencement of the Procedure and not during the course of the procedure. Consent should be procedure-specific and blanket consent is not valid. The patient has the legal and moral right to withdraw the consent during the course of the procedure. Fresh consent should be taken for repeat procedures including the reexplorartion procedure. Consent given for illegal procedures is invalid.

It is therefore necessary for treating doctor to provide all necessary information to the patient before commencing the procedure and this communication should be documented. In the event of an adverse medical outcome, written records of discussion can be doctor's best defense as the court can demand relevant documents of the patient. Even professional indemnity insurance may not cover failure to take valid consent considering it is an intentional assault. 


\section{References}

1) Indian Contract Act, Sec 13; 1872. .

2) Pillay VV. Handbook of Forensic Medicine and Toxicology. Paras Publication. 2003;p. 24-25.

3) Declaration of Helsinki, Original version. In: and others, editor. 18th Meeting. 1964.

4) Berg JW, Applebaum PS, Parker LS, Lidz CW. Informed Consent: Legal Theory and Clinical Practice. 2nd ed. Oxford. Oxford University Press. 2001.

5) Habiba MA. Examining consent within the patient-doctor relationship. Journal of Medical Ethics. 2000;26(3):183-187. doi:10.1136/jme.26.3.183.

6) Sim J. Ethical decision-making in therapy practice. Oxford, Reed. 1997;p. 59-75.

7) Fenety A, Harman K, Hoens A, Bassett R. Informed consent practices of physiotherapists in the treatment of low back pain. Manual Therapy. 2009;14(6):654-660. doi:10.1016/j.math.2009.02.007.

8) Published in Part-III, Section of the Gazette of India. Indian Medical Council (Professional Conduct, Etiquette and Ethics) Regulations, 2002. 2002.

9) Jensen AB. Informed consent. Historical perspective and current problems. Ugeskr Laeger. 1990;152(48):3591-3593.

10) Dr. Ramcharan Thiagarajan Facs vs Medical Council of India on 3 April, 2014. Karnataka High Court. Writ Petition No. 11207/2013 (GM-RES).
2014. Available from: http://www.indiankanoon.com/doc/10293098/.

11) Appelbaum PS, Lidz CW, Meisel A. Informed Consent: Legal theory and clinical practice. New York. Oxford University Press. 1987.

12) TAY CSK. Recent developments in informed consent: the basis of modern medical ethics. APLAR Journal of Rheumatology. 2005;8(3):165170. doi:10.1111/j.1479-8077.2005.00143.x.

13) KSN;Medical jurisprudence and toxicology. vol. 2010. ALT publications. ;p. 148-149.

14) Universal's The code of criminal procedures, 1973. Universal law publishing company private limited. ;p. 34-35.

15) M Y. Age of consent in medical profession. Journal of Indian Academy of Forensic Medicine. 2007;29(2):80-85.

16) Guidelines on Cadaver donor transplants, ethical guidelines for biomedical research on human participants, Indian council of medical research. 2006.

17) The Delhi Artificial Insemination (human) Act1995. .

18) Chapter IV, admission and detention in psychiatric hospital or psychiatric nursing home, The Mental Health Act, 1987. .

19) Section 9 of the principal Act, sub-section (1C), The Transplantation of Human Organs (Amendment Bill, 2011), Transplantation of Human Organs Act, 1994. .

20) Indian Council of Medical Research. Ethical guidelines for biomedical research on human participants. Chapter III, General ethical issues. New Delhi. 2006. 